\title{
Recent changes in ecosystem services and human well-being in the Bangladesh coastal zone
}

\author{
Md. Sarwar Hossain • John A. Dearing • \\ M. M. Rahman • M. Salehin
}

Received: 28 November 2013 / Accepted: 10 December 2014/Published online: 21 January 2015

(C) The Author(s) 2015. This article is published with open access at Springerlink.com

\begin{abstract}
This study takes an historical approach in order to establish how the form and function of the social-ecological system that represents the Bangladesh south-western coastal zone has changed over recent decades. Time series data for a range of ecosystem services and drivers are analysed to define the range of trends, the presence of change points, slow and fast variables and the significant drivers of change. Since the 1980s, increasing gross domestic product and per capita income mirror rising levels of food and inland fish production. As a result, the size of population below the poverty line has reduced by $\sim 17 \%$. In contrast, non-food ecosystem services such as water availability, water quality and land stability have deteriorated. Conversion of rice fields to shrimp farms is almost certainly a factor in increasing soil and surface water salinity. Most of the services experienced statistically significant change points between 1975 and 1980, and among the services, water availability, shrimp farming and maintenance of biodiversity appear to have passed tipping points. An environmental Kuznets curve analysis suggests that the point at which growing economic wealth feeds
\end{abstract}

Editor: Wolfgang Cramer.

Electronic supplementary material The online version of this article (doi:10.1007/s10113-014-0748-z) contains supplementary material, which is available to authorised users.

Md. S. Hossain $(\bowtie) \cdot$ J. A. Dearing

Palaeoecology Laboratory, Geography and Environment, University of Southampton, Southampton SO17 1BJ, UK

e-mail: koushikadd@yahoo.com; Sarwar.Sohel@soton.ac.uk

M. M. Rahman · M. Salehin

Institute of Water and Flood Management (IWFM), Bangladesh

University of Engineering and Technology (BUET),

Dhaka 1000, Bangladesh back into effective environmental protection has not yet been reached for water resources. Trends in indicators of ecosystem services and human well-being point to widespread non-stationary dynamics governed by slowly changing variables with an increased likelihood of systemic threshold changes/tipping points in the near future. The results will feed into simulation models and strategies that can define alternative and sustainable paths for land management.

Keywords Bangladesh - Delta $\cdot$ Ecosystem services . Well-being · Trend analysis · Tipping points

\section{Introduction}

The idea that adaptive management of ecosystems needs to capture the complex dynamics of social-ecological systems (Liu et al. 2007) has rapidly gained ground over the past decade. It is recognised that society requires a more complete understanding of the interactions between social conditions, ecosystems and external drivers than hitherto so that it can respond to environmental feedback and change (e.g. Folke et al. 2005). Ostrom (2007) suggested that such an understanding implies the ability to diagnose the problems and potentialities of social-ecological systems and established a nested, multi-tier framework for this purpose. Biggs et al. (2012) made the case that fostering an understanding of social-ecological systems as complex adaptive systems should represent one of the key principles for managing ecosystem services. But although it is generally agreed that livelihoods, security from disasters and access to key resources may be increasingly dependent upon ecosystem services (MA 2005), it is far from clear how the complex dynamics of ecosystem services can be studied. 
Indeed, Norgaard (2010) argues that the ecosystem service metaphor actually blinds us to the complexity of natural systems. Thus, the implementation of analytical frameworks in the real world to the extent that the complex dynamics of human-environment interactions or ecosystem services are captured sufficiently well to inform management remains challenging (de Groot et al. 2010; Dearing et al. 2012a).

One analytical approach that captures and prioritises complex system dynamics is the co-evolutionary study of coupled systems (Kallis and Norgaard 2010), describing how system properties, such as land use or ecological condition, emerge as a result of multi-scale and bidirectional relationships between human activities and ecological change. In empirical co-evolutionary studies, the emphasis is on mapping the trends and rates of change in key variables in order to show the prevalence of slow adaptation or crisis and the extent to which driver-processresponse interactions are time-lagged. Beddoe et al. (2009) argued that we also need evolutionary frameworks that acknowledge the physical limits to natural resource use (cf. Dearing et al. 2014) if we are to remove barriers to sustainability. Where a long-term, co-evolutionary approach has been tried using a combination of social and biophysical records (e.g. Dearing 2012b), the clarification of the nature of trade-offs between ecosystem services, benefits and economic growth, and the discrimination of 'slow' as opposed to 'fast' processes that underpin resilience (Carpenter and Turner 2001), is greatly improved. In other extended timescale or 'long now' (cf. Carpenter 2002) studies, the approach has revealed the mechanisms by which biophysical tipping points are reached as a result of human actions (Wang et al. 2012) and promises to reveal signs of growing instability across regional social-ecological systems (Zhang et al. 2015).

In this study, we develop further the co-evolutionary approach through description and analysis of multi-decadal changes in social, economic and biophysical variables for a region where the need for enhanced management tools is pressing: the coastal zone of south-west Bangladesh. Our main aim is to use that information to infer the rates and direction of change, the possible existence of transgressed thresholds, the changes in system resilience and the longterm relationship between poverty alleviation and environmental degradation as a foundation for further studies on the social-ecological links and modelling of appropriate management practices.

\section{The Bangladesh delta region}

Recorded statistics of death and destruction alone confirm that Bangladesh is vulnerable to environmental change (Maplecroft 2010; Ahmed et al. 1999). The coastal zone has been affected by 174 natural disasters during the period 1974-2007 (Rahman et al. 2010). An estimated 100,000 people died as a consequence of cyclones in the period 1960-1990 (Ericken et al. 1997). Floods in 1998 caused losses of buildings and infrastructure worth two billion USD (Chowdhury 2001). The area of land lost through riverbank erosion through the period 1996-2000 led to financial losses totalling 540 million USD (Salim et al. 2007). Food security has been severely compromised. Around 1 million tons of food grain were lost to drought in 1997, and $50 \%$ of all grain in 1982 was damaged by flood (Islam 2011). Projections of the likely impacts of climate change highlight substantial decreases in rice and wheat yields within 20-30 years as a result of current increases in annual maximum and minimum temperatures of 0.05 and $0.03{ }^{\circ} \mathrm{C}$ (MoEF 2005). It has been estimated that a sea level rise of $144 \mathrm{~cm}$ by 2050 would cause a $10 \%$ drop in national gross domestic product (GDP) as a result of lost croplands (WB 2000).

The study area contains the world's largest mangrove forest, the Sundarbans. Growing on sediment deposited by the Ganges, it straddles the national boundary between Bangladesh $(60 \%)$ and India $(40 \%)$. This biodiversityrich ecosystem (453 animal species and 22 families of trees representing 30 genera) provides a livelihood for $\sim 3$ million people (Iftekhar and Saenger 2008; Iftekhar and Islam 2004). The Sundarbans protect $>10$ million people from cyclonic storms, but are vulnerable to cyclonic damage, as in 2007 when $\sim 36 \%$ of the mangrove area was severely damaged, leading to losses of livelihood (CEGIS 2007). Construction of dams (Mirza 1998) in upstream channels of the Ganges river system and dykes and polders in the south-west coastal area (Islam 2006) has modified river flows to the mangroves and the balance of freshwater and seawater. These hydrological effects on water quality have been exacerbated by the shrimp farm industry (Swapan and Gavin 2011) over the last two decades.

Thus, there is significant evidence that the Bangladesh coastal social-ecological system is changing more rapidly than before as a result of many different interacting factors including sea level rise, greater storminess, new land uses, modified river flows, population growth, internal migration, urbanisation and stronger conservation measures (ADB 2005). In particular, total population numbers continue to grow despite adoption of family planning measures that have significantly reduced the rate of population growth (WB 2000). This growing complexity of interactions makes assessment of vulnerability to both general and specific pressures at any location even more challenging than before.

Previous studies of temporal and spatial changes in the ecosystems of the Bangladesh coastal zone (BCZ) have 
mainly focused on specific causative links or indicators of change. For example, Adel (2002) was concerned about the temperature change due to water diversion of the Ganges, and Mirza (1998) analysed the water discharges of Ganges over the time period. Few studies have attempted to link changes in biophysical processes to human well-being. Here, we use the ecosystem services concept to focus on the management of natural assets for their values to wellbeing and the complex interlinkages of ecosystem processes for designing adaptive management strategies (Hossain et al. 2013; Binning et al. 2001).

\section{Objectives}

The study aims to provide the basis for a dynamical analysis of the south-west coastal zone of Bangladesh (Fig. 1). This is an area of $\sim 2,550 \mathrm{~km}^{2}$ divided into the nine administrative districts Bagerhat, Barisal, Bhola, Borguna, Jhalokati, Khulna, Patuakhali, Pirojpur and Shatkhira with a total population of $\sim 14$ million, and population densities ranging from $\sim 400$ to 800 people $/ \mathrm{km}^{2}$ (Bangladesh Bureau of Statistics 2011). The Sundarbans mangrove forest (a UNESCO World Heritage Site) extends across $\sim 6,000 \mathrm{~km}^{2}$ of the southern parts of Bagerhat, Khulna, Shatkhira and Patuakhali districts. We draw upon a number of analytical techniques for time series analysis in order to establish how the social-ecological system in the Bangladesh delta zone, as defined by these nine districts, has evolved over past decades. The dynamic baseline is used to diagnose the form and function of the system:
- Which ecosystem services are deteriorating, improving or stable?

- What are the apparent drivers of these trends?

- What has been the importance of shocks and extreme events on ecosystem services?

- Is there any evidence for tipping points or abrupt change points in the trends?

- Which are the 'slow' and 'fast' variables?

- How coupled are the ecosystem services to economic growth and well-being?

- What are the implications for land use and management strategies?

\section{Methods}

We adopt a study framework (Fig. 2) based on the ideas that ecosystem services (e.g. water availability) are derived from ecosystem processes (e.g. nutrient cycling, primary production, soil erosion) (Fisher and Turner 2008) and that these services have impacts on human well-being (MA 2005). Ecosystem processes are the basis of ecosystem services (de Groot et al. 2010) but are currently omitted here due to lack of data (e.g. primary production). However, ecosystem processes are increasingly discriminated from ecosystem services in order to avoid double counting (Petz et al. 2012; de Groot et al. 2010). Ecosystem services indicators (Table 1) have been selected based on the study framework, data availability, measurability and current
Fig. 1 Bangladesh delta zone study area showing location in Bangladesh (inset), the three greater districts and the Sundarbans

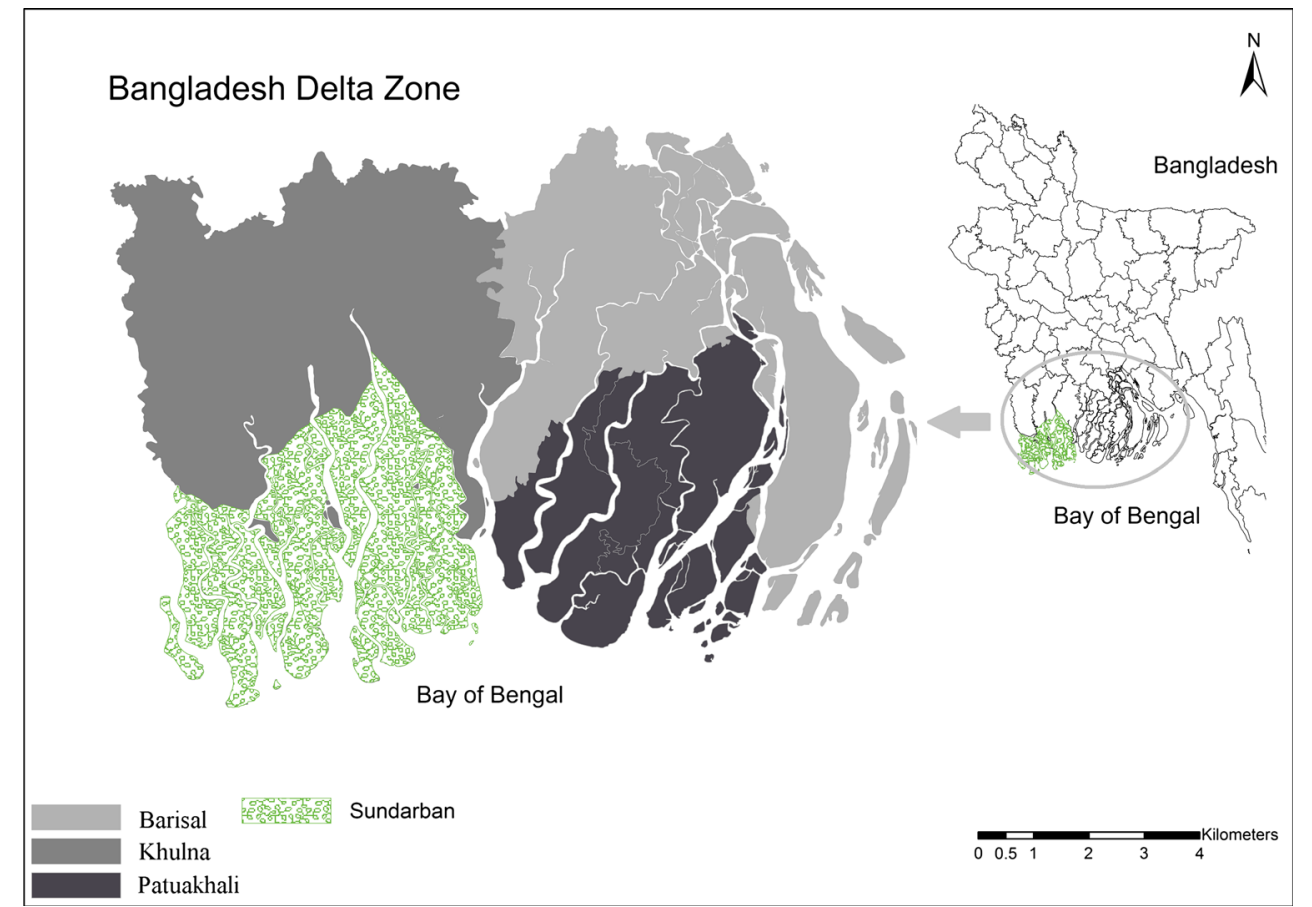


Ecosystem Services and Poverty

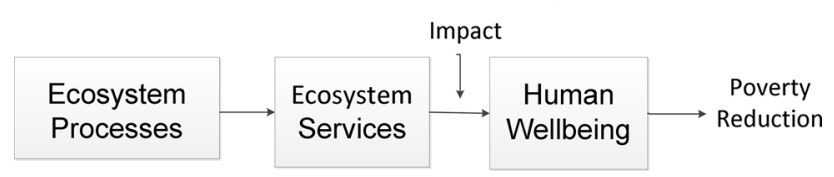

Fig. 2 Linkage between ecosystem services and human well-being (adapted from Fisher et al. 2008 and MA 2005)

environmental concerns (e.g. increasing soil salinity). Human well-being is the subset of economic and social conditions (OECD 2001), such as security, health, social freedom and choice, which are essential elements for life (MA 2005). The list of indicators including the data sources is given in Table 2 and Supplementary Information (SI). Our framework neither avoids making a priori definitions of drivers of environmental change nor assumes that strong causative links between variables are present.

Time series of indicators for the ecosystem services (Table 1) and human well-being are partly based on annual official data available for the nine districts, partly on data available for the Sundarbans National Park, and partly on ad hoc time series of monitored point data or sequences of mapped data from hydrological, climatological and agricultural organisations, and other scientific studies. Where possible, we aggregate district-level data collected since 1985 from the nine districts into three sets that are equivalent to the three larger 'greater districts' or 'regions' of Barisal, Khulna and Patuakhali, which existed before 1985 (Fig. 1). Together with pre-1985 data from each of the regions, we construct time series from the present (2010) back to the 1970s where possible (Table 2). We refer specifically to the study area comprising these three regions as the BCZ. Throughout the paper, data records are labelled by the names of the three regions (Barisal, Khulna and Patuakhali). Data for the Sundarbans National Park are referred to as mangrove forest that stretches across the three regions, and other time series are labelled according to the region of origin.

Food, shrimp, fish and raw materials, including timber, are selected to show the trajectories of provisioning services. People of the delta depend on a variety of crops, such

Table 1 Indicators for ecosystem services

\begin{tabular}{|c|c|c|}
\hline $\begin{array}{l}\text { Ecosystem } \\
\text { services }\end{array}$ & Indicators & Data sources \\
\hline \multicolumn{3}{|c|}{ Provisioning services } \\
\hline $\begin{array}{l}\text { Food } \\
\text { production }\end{array}$ & $\begin{array}{l}\text { Rice (T- and HYV-Aus, T- and HYV-Aman, T- and } \\
\text { HYV-Boro) } \\
\text { Vegetables } \\
\text { Potato } \\
\text { Sugarcane, Jute, Onion, Spices (Garlic, Ginger, Turmeric } \\
\text { and Coriander) } \\
\text { Fish } \\
\text { Shrimp } \\
\text { Honey }\end{array}$ & Bangladesh Bureau of Statistics (BBS) \\
\hline Forest products & Timber types (Glopata, Goran, Gewa), BeesWax & $\begin{array}{l}\text { Department of Forest, Khulna, Bangladesh; Zmarlicki 1994; } \\
\text { Chaffey et al. } 1985\end{array}$ \\
\hline \multicolumn{3}{|c|}{ Regulating services } \\
\hline Water quality & Surface water salinity Soil salinity & Uddin and Haque (2010) Islam (2008) \\
\hline Local climate & Temperature and precipitation & Bangladesh Meteorological Department \\
\hline $\begin{array}{l}\text { Water } \\
\text { availability }\end{array}$ & River discharge Groundwater level & Bangladesh Water Development Board \\
\hline $\begin{array}{l}\text { Natural hazard } \\
\text { protection }\end{array}$ & $\begin{array}{l}\text { Crop damage (due to cyclones, flooding, water logging } \\
\text { and excessive rainfall) }\end{array}$ & Bangladesh Bureau of Statistics (BBS) \\
\hline $\begin{array}{l}\text { Erosion } \\
\text { protection }\end{array}$ & Fluvial erosion and accretion & Mapped data Rahman et al. 2011 \\
\hline \multicolumn{3}{|l|}{ Habitat services } \\
\hline $\begin{array}{l}\text { Maintenance of } \\
\text { biodiversity }\end{array}$ & $\begin{array}{l}\text { Mangrove density; Mangrove volume; Mangrove area; } \\
\text { Mangrove floristic composition, tiger and deer }\end{array}$ & $\begin{array}{l}\text { MoEF (2010); Dey (2007); Khan (2005) FAO (2007); FAO 1999, } \\
\text { MoEF (2002): Chowdhury 2001; Helalsiddiqui 1998; Gittings } \\
\text { 1980; Hendrick } 1975\end{array}$ \\
\hline \multicolumn{3}{|l|}{ Cultural services } \\
\hline $\begin{array}{l}\text { Recreational } \\
\text { services }\end{array}$ & Number of tourist visitors & IUCN, 1997; Department of Forest, Khulna \\
\hline
\end{tabular}


Table 2 Indicators for human well-being. Details are given in SI

\begin{tabular}{llc}
\hline Indicators & Objective & Data source \\
\hline $\begin{array}{l}\text { Poverty (\% of population below } \\
\text { poverty line) }\end{array}$ & Measures the deprivation & Bangladesh Bureau of \\
Per capita income & Sell-being in the society & Statistics (BBS) \\
Gross domestic product & Measures individual personal wealth & Deb (2008) \\
& Measures the aggregated indices of well-being, & Bangladesh Bureau of \\
& encompasses of human and natural production & Statistics (BBS) \\
\hline
\end{tabular}

as different varieties of rice, jute and sugarcane. Temperature and precipitation are used as the performance indicators of local climate (WRI 2013; De Groot et al. 2006). Fluvial erosion and floodplain accretion rates are the performance indicators for erosion prevention. We choose the time series statistics of crops naturally damaged by different disasters (flood, cyclone, water logging etc.) to analyse the trends of natural hazard mitigation. For indicators of biodiversity (Costanza et al. 1997 and De Groot et al. 2002), we use trees per hectare (ha), growing stock and the number of Royal Bengal tigers and deer in the mangrove forest. The mangrove forest covers $\sim 28 \%$ of the study area with $\sim 10$ million people directly and indirectly dependent on the ecosystem services it provides. Moreover, the total coastal ecosystem produces around US\$277 GDP per capita (Sarwar 2005). Collections of raw materials (mainly forest products) from the mangrove are secondary occupations. However, biodiversity data for other parts of the study area are not available. Missing values amount to $<5 \%$ for most indicators (e.g. rainfall and water discharge), and these were analysed using statistical test (e.g. Mann-Kendall test) that assumes continuous series. Where time series data (e.g. raw materials, mangrove area and per capita income) were limited to specific years, these are shown only as simple plots.

Continuous series are expressed in raw and normalised $\mathrm{z}$ score forms (Wünscher et al. 2008). The data were analysed using linear regression and nonparametric MannKendall statistics (MK stat) and the Lepage test in order to discriminate between improving, deteriorating and stable trends and to identify statistically significant change points. We have applied the nonparametric Mann-Kendall trend test to detect trends in the time series data of water discharges, ground water level, rainfall and temperature. High variability and nonlinear system characteristics are the reasons for applying this nonparametric test. The MannKendall test has already been applied in detecting temperature (Vitale et al. 2010), precipitation (Hossain et al. 2014; Serrano et al. 1999) and river flow data (Danneberg 2012). The nonparametric Lepage test was also applied to detect change points in the trajectories of ecosystem services. The Lepage test has been used to detect change point or stepwise change for rainfall (Hossain et al. 2014), climate change (Inoue and Matsumoto 2007) and water resources (Zhang et al. 2009).

Aggregated and smoothed indices are produced from mean z scores in order to compare trends in different sets of indicators. The main rice crop is used as the index for food provisioning services. The trajectory of salinity has been reversed to represent a water quality index. Lowess smoothing has been applied to these entire indices before plotting. Lowess is the process of time series smoothing similar to running mean of about 15 years that removes the high and low frequencies from the time series data (Wilkinson 1997). This smoothing method is already applied to climate-related (Brazel et al. 2000) and water-quality-related (Hirsch et al. 1991) studies.

We have analysed the controls on the value-added production from agriculture and revenue from the mangrove forest products using bivariate plots, Spearman's Rank correlation coefficient and the literature review. Trend observations and bivariate plots are used to discriminate between slow and fast variables. We have attempted to identify slow and fast variables of ecosystem services, where the slow variables are the controlling and shaping variables for system resilience (Biggs et al. 2012; Walker et al. 2012). The literature review, bivariate plots and correlation analysis are used to identify the drivers of changes in relation to the observed trends and identifying the tipping points. Environmental Kuznets curves are used to show the relationship between wealth and environmental degradation over the time. This curve hypothesises that at an early stage of development, environmental degradation increases, but beyond some level of economic growth, environmental degradation declines (Grossman and Krueger 1995). Further details on the study area and methodology are given in SI.

\section{Results}

Provisioning services

Food production in the $\mathrm{BCZ}$ is mainly derived from agricultural and aquacultural goods with a very small amount 
directly from ecosystem services (e.g. wild fish and honey). Since 1970, the net cultivated crop area of the BCZ (SI Figure 1) has fluctuated between $\sim 1,093$ and $1,295 \mathrm{~km}^{2}$ with a current figure (2009) of $\sim 1,200 \mathrm{~km}^{2}(300,000$ acres), which represents $\sim 47 \%$ of the total land area. Despite the fairly constant figures for crop area (SI Figure 1), regional rice production across the $\mathrm{BCZ}$ rose twoto fivefold between 1969 and 2010 (SI Figure 2 and SI Figure 3 for combined values since 1948). Rice production in Khulna, Barisal and Patuakhali steadily rose from 1969 to 2010 reaching highest values after 1998, although notable minima are recorded for Khulna in 1980-1981, 1998 and 2007-2008 and for Barisal in 1982 and 1995-1998. Rice varieties fall into two groups: the traditional (T), local varieties (T-Aman, Aus, and Boro) types and the introduced high-yielding (HYV) varieties (HYVAman, Aus and Boro). Since 1969, the T-Aman has been the dominant variety across the $\mathrm{BCZ}$, showing peak production figures in the mid-late 1980s (SI Figure 3). Since the 1980s, production figures for HYVs across the three regions have more than tripled, especially for HYV-Boro and HYV-Aman, with HYV production only exceeding that for T-Aman after the mid-2000s. The major rice varieties, except HYV-Aman, experienced a dramatic decline in 2007-2008. Records for sugarcane and jute production across the BCZ since 1969 show a declining trend since the 1970s, but production figures for both summer and winter vegetables and spices have risen since the 1990s. Potato production rose sharply in the 1990s, but since 2001, it shows a rapidly falling trend (SI Figure 4).

About 100,000 $\mathrm{t}$ of shrimp and fish are produced each year with $\sim 30 \%$ from rivers and estuaries and $<5 \%$ from the natural wetlands (Sundarbans, beels and baors). The large majority comes from artificial ponds and fish farms. Data for fish production since 1986 (SI Figure 5) show major changes in the use of different aquatic ecosystems and artificial systems. Production from rivers and estuaries declined dramatically in the 1980s and 1990s mirroring the increasing production from artificial ponds and shrimp farms that continues to the present. Aquacultural production figures for shrimp and fish across the BCZ since 1984 show step change increases in the 1990s when total production rose at least fourfold within a decade (SI Figures 5 and 6). Since then, annual shrimp production has risen from $\sim 5,000$ to $>25,000 \mathrm{t}$ and fish production from ponds has risen from $\sim 22,000$ to $\sim 60,000 \mathrm{t}$. Shrimp and fish production figures are significantly higher in Khulna $(>20,000 \mathrm{t})$ than Barisal $(<50 \mathrm{t})$ and Patuakhali $(<900 \mathrm{t})$. Trends in timber and related natural materials from the Sundarbans mangrove forest appear to have reached a maximum in the 1980s-1990s (data are missing 1987-1991) before declining steeply after 1997. Honey collection shows less of a trend with relatively low values in the 1970s and 1980s, and high values during the period 1996-2000 and 2007-2008. Overall honey collection increased by $1.7 \mathrm{t}$ per year in the period 1974-2010 (SI Figure 7).

\section{Regulating services}

Salinity concentrations in the Poshur river at Mongla Khulna increased steadily (SI Figure 8) from $<5,000 \mathrm{~S}$ $(<5 \mathrm{dS} / \mathrm{m})$ in the early 1970 s to $>50,000 \mathrm{~S}(>50 \mathrm{dS} / \mathrm{m})$ in 2005. Similar salinity levels were found in rivers in the Rampal and Paikgacha areas until 1995, but these were followed by a steep decline in the late 1990s. The three salinity curves suggest that values for river salinity in 2005 stood at $\sim 35,000-50,000 \mathrm{~S}$, representing a two- to tenfold increase since the 1970s.

Soil salinity measured in dry and wet seasons for three sites in Khulna and four sites in Patuakhalia since the 1990s shows contrasting records, with generally higher and increasing values in Khulna. In Khulna, salinity values increased from $<5 \mathrm{dS} / \mathrm{m}$ to reach peak values $>10 \mathrm{dS} / \mathrm{m}$ in the 2000s, with maximum annual figures exceeding $20 \mathrm{dS} /$ $\mathrm{m}$. Recent years (since 2006) show contrasting trends between the seasons with wet season salinity decreasing and dry season salinity increasing. Soil salinity in the Patuakhali region shows lower absolute values (always $<5 \mathrm{dS} / \mathrm{m}$ ), even though it is closer to the sea than Khulna and has only slight rising trends towards the present (SI Figure 9). Modelled nutrient loading (total fertiliser and manure input) for three locations in the study area (Global NEWS model) suggests more than a doubling in the application of fertiliser and manure between 1970 and 2000: $18 \mathrm{t} / \mathrm{km}^{2} /$ year in 1970 to $39 \mathrm{t} / \mathrm{km}^{2} /$ year in 2000 .

Daily rainfall data (SI Figure 10) from three stations are shown for the pre-monsoon, monsoon, post-monsoon and winter periods from 1948 (Barisal and Khulna) or 1973 (Patuakhali) to present. Mean daily rainfall figures are generally in the range $15-30 \mathrm{~mm} /$ day with extreme lows $(<5 \mathrm{~mm} /$ day $)$ in Khulna in 1971 and extreme highs (>45 mm/day) in Barisal in 1955 and 1960, and in Patuakhali in 1983. Monsoon and post-monsoon rainfall trends show increasing trends (MK stat 0.67 and 2.53, respectively) over the period 1948-2012. However, both of seasons are following negative trends since 1990 . Monsoon is following a significant (95\%) sharp decreasing trend ( $48 \mathrm{~mm} /$ season/day, MK stat -1.77$)$, whereas post-monsoon follows a non-significant declining trend $(11 \mathrm{~mm} /$ season/day, MK stat -0.70) from 1948 to 2012. Rainfall trends in $\mathrm{BCZ}$ also reflect in regional scale except in Barisal, where post-monsoon rainfall shows a non-significant increasing trend. Though the rainfall trends show decreasing trends since 1990, rainfall mostly declined (from $<15$ to $>15 \mathrm{~mm} / \mathrm{season} /$ day) after 2007. Moreover, Mann- 
Kendall test statistics are also found to be significantly positive for the time period 1991-2007; in contrast, test statistics are found to be negative for the period 1991-2012. Pre-monsoon rainfall figures show a wide range of values between the three stations with Khulna generally showing the lowest (typically $<5 \mathrm{~mm} /$ day) and Barisal the highest (typically $>10 \mathrm{~mm} /$ day). There is a nonsignificant decreasing trend at all three sites over the time period 1948-2012 with a more sharply decreasing trend (overall $-34 \mathrm{~mm} / \mathrm{season} /$ year, MK stat -3.35 , confidence interval $99 \%$ ) since the 1990s. Winter rainfall figures show generally low values (typically $<2 \mathrm{~mm} /$ day) with a period of relatively high values in the 1990s. In all three regions, At Khulna and Barisal there are significant trends for increasing rainfall $(5-8 \mathrm{~mm} / \mathrm{season} /$ year; $\mathrm{MK}$ stat 0.7-2.85) for the period 1947-1990, and decreasing trends (3-6 mm/season/year; MK stat: $-1.5-2.79$, confidence interval 85-99 \%) after the 1990s. Overall, the BCZ shows a trend since the 1990 s towards weakening monsoons and pre-monsoon with the timing of non-monsoon rainfall shifting from the monsoon to the post-monsoon period except after 2007. Temperature data (SI Figure 11) are shown for pre-monsoon, monsoon, post-monsoon and winter seasons for Barisal, Khulna and Patuakhali from 1947. Absolute differences between the stations are small, but there are significantly increasing trajectories in all four seasons over the period. Pre-monsoon, monsoon and postmonsoon temperatures showed increasing trends $\left(\sim 0.02{ }^{\circ} \mathrm{C} /\right.$ year; MK stat $\sim 2$ ) after the 1990 s (confidence levels 95-99\%).

River discharge data from Hardinge Bridge on the river Padma (Ganges) are shown for the period 1931-2010, split into pre-monsoon, monsoon, post-monsoon and winter seasons (SI Figure 12). Significant control of water flow occurred after 1975 when the Farakka barrage (in India to the north) came into operation. Winter dry season river discharge declined significantly from $\sim 2,000$ to $4,000 \mathrm{~m}^{3}$ / $\mathrm{s}$ before 1975 to below 1,000-2,000 $\mathrm{m}^{3} / \mathrm{s}$ after 1975 . Exceptions to this trend were observed only in 2000-2001 and 2007 as a result of extreme flood events. The overall trend in the dry season has declined at a rate of $10 \mathrm{~m}^{3} / \mathrm{s} /$ year in the period 1965-2010 (MK stat -1.67; confidence level $90 \%$ ). River discharge in the wet season (monsoon and post-monsoon) shows figures of $\sim 1,500-2,500 \mathrm{~m}^{3} / \mathrm{s}$ with small declines (28 and $47 \mathrm{~m}^{3} / \mathrm{s} /$ year) in the postFarakka period. Relative changes (SI Figure 13) show similar long-term patterns in all seasons, but emphasise the relatively lower dry season discharge from 1975 to the late 1990s.

Ground water levels (SI Figure 14) for four sites across Khulna and Barisal are shown as mean depths of ground water for pre-monsoon, monsoon, post-monsoon and winter periods since the 1970s. Data for Dacope (Khulna) show that groundwater has been rising over the period (0.04 m/year; MK stat >3.68; confidence level $95 \%$ ) in all four seasons. In contrast, the data for Rupsha (Khulna) show no overall trends except for a weak trend in the monsoon season towards deeper levels. At Gouronodi (Barisal), there is a trend of rising groundwater $(0.02 \mathrm{~m} /$ year; MK stat 2.9; confidence level $95 \%$ ) in the drier seasons. At Bakergonj (Barisal), there are significant trends (confidence level $95 \%$ ) towards lower groundwater in monsoon and post-monsoon seasons. Overall, dry season (pre-monsoon and winter) groundwater levels were lowest in the 1980s and since then have risen at three sites. Groundwater levels in the wetter seasons (monsoon and post-monsoon) are generally higher and show weaker trends. For Barisal, there has been an inter-seasonal convergence of groundwater levels.

Crop damage figures for the BCZ from natural disasters, including flooding, cyclones and water logging, extend back to 1963 (SI Figure 15). The figures show recorded damage in $35 \%$ of years (16 years in the complete series to 2009) with three clusters (at least three consecutive years) of years 1963-1969, 1981-1991 and 2006-2009. Highest levels of damage are recorded for 1965, 1988 and 2007 with total agricultural losses (tonnes grain) estimated at $\sim 290,000,500,000$ and 600,000 t. The last two of these disasters are linked to the impacts of the extreme floods in 1987-1988 and super-cyclone SIDR in 2007. The frequency of severe cyclonic storms with hurricane intensity doubled over the period 1991-2007 compared with 1960-1990 (SI Figure 17).

Data for accretion and erosion rates (SI Figure 17) along the major rivers of the Sundarban side of the BCZ since the 1970s show that erosion has been greater than accretion in all decades except the 1980s. Mean erosion rates have decreased from $23 \mathrm{~km}^{2} /$ year in the 1970 s to $<10 \mathrm{~km}^{2} /$ year in the 2000s, but mean accretion rates have also declined from 9 to $3 \mathrm{~km}^{2} /$ year in the same period. The most recent estimate of net land loss is $\sim 6 \mathrm{~km}^{2} /$ year. However, there is also evidence that accretion rates around the Meghna estuary (alongside the region Barisal and Patuakhlia) are increasing. Though the net land loss and gain fluctuated over the time from 1973 to 2010, the most recent estimate of land gain is $\sim 3 \mathrm{~km}^{2} /$ year since 2001 .

\section{Habitat and cultural services}

The total area of mangroves has increased over the period 1959-2000 (SI Figure 18), while tree density and growing stock have declined substantially. The growing stock of mangrove forest is estimated to have halved (from 20 to $10 \times 10^{6} \mathrm{~m}^{3}$ ) between 1956 and 1996 (SI Figure 19), a pattern mirrored in the reduction of tree density, including the main types Sundari (Heritierafomes) and Gewa 
(Excoecariaagallocha), from 300 to 150 trees per ha in the same period (SI Figure 20). Numbers of deer (SI Figure 21) in the mangrove forest show fluctuating numbers (50,000-95,000) since 1975, but numbers of tigers (SI Figure 22) seem to have peaked at $\sim 450$ in 1982 and 2004 with a decline to 200 in 2007. Data are available for the total number of tourists visiting the Sundarbans between 1996 and 2004 (SI Figure 23). Figures show 5,000 visitors/year from 1996 to 2004 rising to 25,000 in the period 2010-2011.

\section{Population and human well-being}

Total population in the BCZ decreased from $\sim 9$ million in 1974 to $\sim 8.5$ million in 1991 , with an increase since then to $\sim 14$ million in 2011 (SI Figure 29). In 2011, the rural population made up $\sim 80 \%$ of the total population. The urban population rose from 1974 to reach a peak at $\sim 2$ million in 2001 before falling back to slightly lower levels in 2011. The rural population declined from $\sim 8$ million in 1974 to $\sim 4$ million in 1991 and rose to $\sim 12$ million in 2011. Over a 40-year period, the population in Barisal and Khulna rose from $\sim 3.5$ to 6 million and rose from $\sim 1.5$ to 2 million people in Patuakhali.

Total GDP across the BCZ increased from 74 million USD to around 1,025 million USD in the period 1978-2005 (SI Figure 24). Sharply increasing trends date to the late 1980s (GDP 200-600 million USD) and late 1990s (GDP 600-1,000 million USD). Barisal, Khulna and Patuakhali all show similar trends, but Patuakhali currently has a significantly lower GDP ( $<400$ million USD) than the others $(>1,000$ million USD). Per capita income (Figure 27) is currently highest in Khulna (559 USD) followed by Patuakhali (393 USD) and Barisal (358 USD). Comparison with past decades suggests that the rate of increase in per capita income has been greatest in Khulna and least in Patuakhali. Rising levels of per capita income and GDP have resulted in a reduction since 1995 in the numbers of people classified as living below the poverty line (SI Figure 25). Current (2010) levels of poverty (SI Figure 26) for Khulna and Barisal are $33.4 \%$ and $39.6 \%$, respectively, of the total population, down from 59.5 to $47.2 \%$, respectively, in 1983. Population numbers lying below the poverty level have declined by $\sim 17 \%$ across the BCZ since 1995.

Figures for total value-added income (SI Figure 27) (at current prices) derived from agriculture and fishery across the BCZ are only available for the period 1977-1995. There was a major step increase around 1983 (to be validated), followed by a decline in 1992 and a rise to 1995 . Figures for total revenue (SI Figure 28) derived from the Sundarbans are available from 1974 to 2011 and show peak values in the 1980s and 1990s with a steep decline to the present day (Figure 30). Current income from the Sundarbans is estimated at 2-3 million BDT. In 1995, the last year when the two sets of data can be compared, the income from the Sundarbans (225 million BDT) was equivalent to $0.06 \%$ of the total value-added income from agriculture and aquaculture (35 billion BDT).

Social-ecological dynamics

We use normalised records (averaged where there are more than two indicator records) for each category of ecosystem service and human well-being since 1949 to summarise the major trends and system dynamics (Fig. 3; Table 3). The majority of ecosystem services are declining, in the sense of deteriorating (Fig. 3). Only food production and cultural services, and water availability, are improving. For some ecosystems, the question of deterioration depends upon the precise nature of the indicator. For example, the area of mangrove forest may be relatively stable but mangrove density has declined since the 1950s. Although some nonfood ecosystem services are declining, there are several positive changes in human well-being. The total GDP of the BCZ increased from 74 million USD to around 1,025 million USD in the period 1978-2005, resulting in a strongly increasing trend of per capita income. The size of population existing below the poverty line declined dramatically in the 1990s. The number of tourists visiting the Sundarbans has increased significantly after 2000. In dynamical terms, the most striking feature of the data (Fig. 4) is the dominance of trending lines and the lack of stationary curves. GDP, food production and water quality show the largest relative changes with both covering $>2.5$ standard deviation units. The rise in GDP is the most dramatic as it occurs in less than half the timescale of the others. Changes in water availability and groundwater levels are relatively smaller owing to reversal and slowing of the trends after the late 1980s and mid-1990s, respectively. Local climate shows a rising trend after 1980 reflecting increases in both monsoon and post-monsoon rainfall, and higher temperatures.

\section{Discussion}

Ecosystem service trends

In the past three decades, there have been a number of changes in crop production, fishery output and raw materials availability. Production of HYV rice and some local rice varieties has increased, and although the production of some of the other local crops (T-Aman rice, sugarcane, jute) has declined, the overall production of regional food has accelerated since the 1980s. Changes in three sub- 
Fig. 3 Trends for the different indicators index of human wellbeing (a), cultural and habitat services (b) and regulating and provisioning services (c)
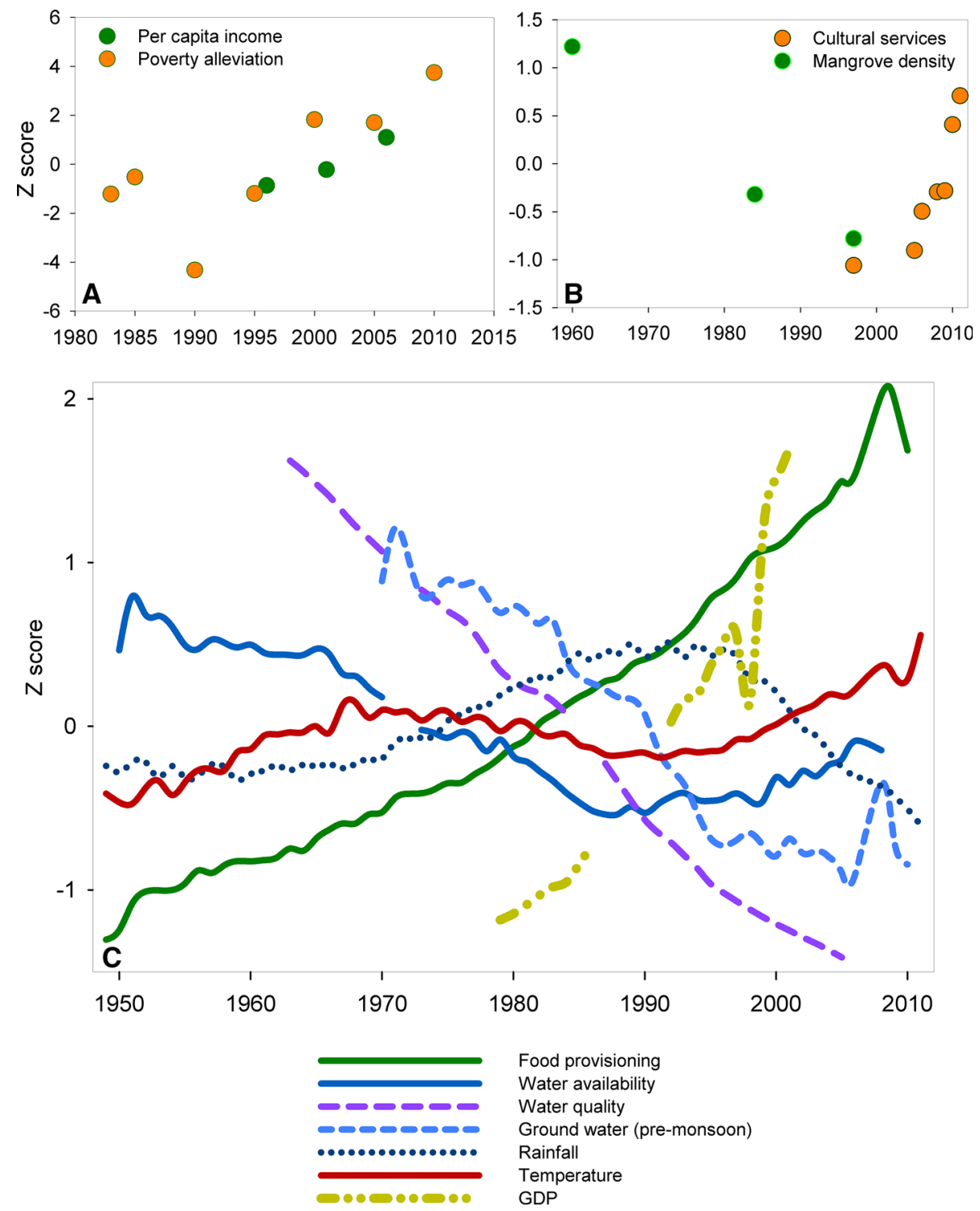

regions are consistent with the whole regional trend. Similarly, both shrimp and fishery production have increased over the same period, although shrimp production $(>5,000 \mathrm{t})$ remains higher than fish production $(<3,000 \mathrm{t})$. Around $80 \%$ of shrimp production is obtained from the Khulna region. Meanwhile, in the mangrove, honey collection increased between 1980 and 2000, but declined around 2007-2008. Also, the collection of raw materials (mainly forest products) has declined since 1996.

Water quality and hydrological regimes are the substantial ecosystem services that are deteriorating after the 1980s. River water salinity stood at levels between 20,000 and 45,000 mS between the periods 1980-2008. Not only the river salinity is increasing, but also the nutrient load to watersheds shows an increasing trend within a very short period of time. Similarly, soil salinity also increases in the delta region, where soil salinity is higher in greater Khulna regions than Potuakhali region. Although the rainfall is declining in pre-monsoon, monsoon and post-monsoon seasons, the monsoon and post-monsoon seasons exhibit increasing trends up to 2007, followed by declining trends. However, temperature is rising across the whole BCZ in each season except winter, where it is been declining since the 1990s.

Human well-being shows an improving trend in the BCZ. The GDP trend is rising at a rate of 50 million USD/ year over 15-20 years with per capita income increasing $\sim 100$ USD over the same period. Increasing trends of average human well-being have led to a reduction in poverty by $\sim 17 \%$ over the same 15 years. But while the urban population shows no trend, the rural population has increased similar to the total population trend. The trend of 
Table 3 Dynamical state of final ecosystem services including slow and fast variables and major shifts, with potential drivers of change over past decades

\begin{tabular}{|c|c|c|c|c|}
\hline Ecosystem service & Dynamic state & $\begin{array}{l}\text { Fast or slow } \\
\text { variable }\end{array}$ & $\begin{array}{l}\text { Date of major shift in } \\
\text { trend }\end{array}$ & Potential drivers \\
\hline Food production & Improving & Slow & 1985 & Population and technology \\
\hline Forest products & Deteriorating & Slow & 1996 & Water availability and water quality degradation \\
\hline Water quality & $\begin{array}{l}\text { Deteriorating/ } \\
\text { improving }\end{array}$ & Fast/slow & $1980-1985$ & $\begin{array}{l}\text { Water availability reduction, polders and shrimp } \\
\text { industry }\end{array}$ \\
\hline Local climate & Deteriorating & Fast/slow & 1990 & Global climate change \\
\hline Water availability & Deteriorating & Fast/slow & 1975 & Farakka Barrage in the upstream \\
\hline $\begin{array}{l}\text { Natural hazard } \\
\text { protection }\end{array}$ & Deteriorating & Slow & 1990 & Increased intensity of cyclones \\
\hline Erosion protection & Deteriorating & Slow & 1990 & Water availability fluctuation \\
\hline $\begin{array}{l}\text { Maintenance of } \\
\text { biodiversity }\end{array}$ & Deteriorating/stable & Slow & & Shrimp farming, water availability reduction \\
\hline Cultural services & Improving & Slow & 2005 & Policy \\
\hline
\end{tabular}

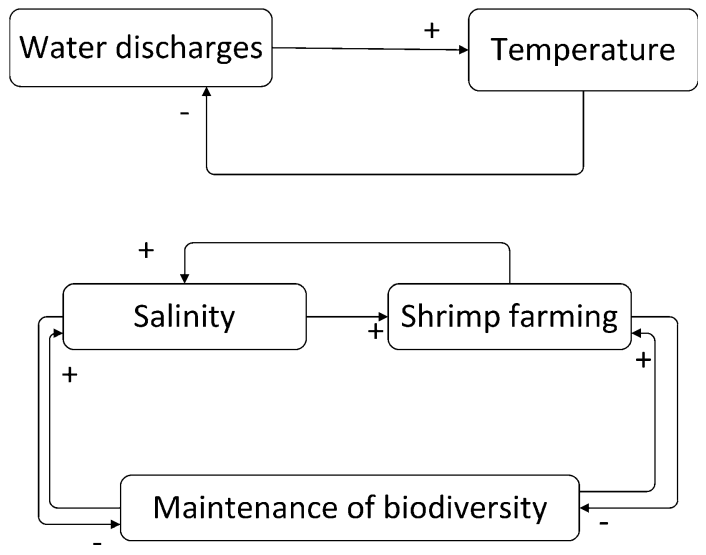

Fig. 4 Changes in water resources, temperature and maintenance of biodiversity become self-perpetuating through positive feedback loops, which is one of the characteristics (CBD 2010) of tipping points. Shrimp farming increases salinity, which reduces mangrove diversity, and leads to increased salinity in the system. Moreover, shrimp farming also reduced mangrove diversity, which also favoured shrimp farming because of the high suitability of mangrove area for shrimp farming. Besides this positive feedback for shrimp farming, changes in water discharges and temperature become self-perpetual through the feedback loops, in which reduction in water availability because of Farakka dam increases temperature, which leads to decrease in water availability

the total population is increasing, but has not experienced any major shift compared to ecosystem services and human well-being.

Social and biophysical drivers

Preliminary analysis based on correlation, published data and trend observation (Table 3) suggests that there are multiple drivers of ecosystem service change that range from global climate change and new agricultural methods to specific infrastructural developments (e.g. the Farakka barrage and polders), and local-policy-driven actions (e.g. commercial shrimp farming).

It is observed from the correlation analysis that HYV rice varieties (SI Table 2 and SI Figure 30) exhibited a significant negative $(r=-0.45)$ relationship with premonsoon rainfall and a significant positive $(r=0.2-0.8)$ relationship with temperature. In addition, some of the rice varieties (e.g. HYV-Aus and HYV-Boro) are showing stronger relationships with temperature after the 1990s. However, a crop variety like T-Aman shows a negative $(r=-0.3)$ relationship with post-monsoon temperature after the 1990s, whereas the relationship was positive ( $r=\sim 0.45$ ) before the 1990s. Similarly, though the HYV rice varieties exhibited negative relationships with premonsoon rainfall, they were positive relationships before the 1990s, indicating that the decreasing trend of premonsoon rainfall favoured the HYV rice production. Moreover, a negative association $(r=\sim-0.5)$ between temperature and local crops (e.g. jute, sugarcane etc.) indicates that the increasing trends of HYV crops were favoured by the increasing trends of temperature (premonsoon to post-monsoon) and the declining rainfall trend in the pre-monsoon season. Though the climate variability favoured the HYV crop cultivation, technological innovation (Husain et al. 2001; Ali 1999) aimed at meeting the food demand for an increasing population was an important reason for adopting these crops.

Conversion of rice fields into shrimp farming appears to have been favoured by the rising trend of salinity which reduced the accessibility of forest products. Our correlation coefficient results $(r=0.99)$ confirm that the salinity increase (Swapan and Gavin 2011) promoted by 
polderisation and flood control projects in 1960s produced an environment that was favourable for shrimp cultivation (Islam 2006; Mirza and Ericksen 1996). In turn, this led to the destruction of around 9,500 ha of mangrove forest (Azad et al. 2009) followed by reduced accessibility of forest products $(r=\sim 0.59$ ) due to imposed regulations (Iftekhar and Islam 2004). Though the explosion in the shrimp industry influenced the rising trend of salinity, the negative $(r=-0.60)$ relationship between pre-monsoon water discharges and salinity indicates that the reduction in water availability was another factor for the salinity rise. Our trend statistics and change point analysis of water discharges are all consistent with the timing of the Farakka dam between 1965 and 1975 (Mirza 1998 and Mirza 1997). Moreover, the declining trend of pre-monsoon water discharge is negatively associated $(r=\sim-0.5)$ with premonsoon temperature and ground water level. At the coast, river discharge maintains the pressure to counter sea water intrusion. Thus, the rising levels of ground water level possibly reflect the reduction in water availability from upstream discharge and the increasing risk of sea water contamination (Rahman et al. 2011; Bahar and Reza 2010).

\section{Resilience, shocks and tipping points}

A preliminary assessment of the indicator variables as 'slow' or 'fast' suggests that all the variables have a slow component, as defined by the presence of trends over decadal timescales. But some indicator variables also show fast- or high-frequency components over annual and shorter timescales, particularly water quality, rainfall and water availability (Table 3). System resilience depends upon the interactions between fast and slow variables. The observation that many of the deteriorating non-food ecosystem services that regulate and support key ecosystem processes are exhibiting slow components may indicate weakening resilience within the dependent agriculture and aquaculture sectors. This is especially important because the BCZ is historically vulnerable to high-magnitude lowfrequency events in external drivers. Flooding and severe cyclones, particularly in 1987-1988, 1991 and 2007, are the major shocks which have impacted on food production. The statistics suggest that the flooding between 1984 and 1990 together with the cyclone in 1991 may have affected negatively the percentage of population lying below the poverty level which rose to $63 \%$ in 1991 from a level of $50 \%$ in 1985. There is evidence for an increasing frequency of stronger cyclones since 1990 as a result of climate change (Khan et al. 2000 and Ali 1999). This combination of declining resilience and increased incidence of extreme events raises the prospect of a "perfect storm' scenario (Dearing et al. 2012a) with a greater likelihood of tipping points. It is difficult to define precise dates for when the services shifted towards deterioration or improvement, but the evidence suggests a range of decades (Table 3 and SI Table 2-13). Lepage test and nonlinear test results (SI Table 2-13) show that the shift towards deteriorating trends occurred in the mid-1970s (water availability and temperature), mid-1980s (water quality), early 1980s and 2007 (rainfall), and early 1990s (ground water level). Shifts towards improving trends occurred in the 1980s (food production) and in the 2000s (cultural services). In addition, change point analysis reveals that food production shifted towards improving trends in 1959, 1977 and 1999. Though the change point analysis does not necessarily imply a tipping point or regime shift to an alternative state, some of the ecosystem services such as water availability, water quality and maintenance of biodiversity may have passed tipping points because there are easily observed positive feedback loops within the system (cf. Wang et al. 2012). For example, the rise in salinity and deterioration in water quality encourage shrimp farming which in turn accelerates the process of localised salinisation (Fig. 4).

Ecosystem services, economic growth and well-being

Bivariate plots (Figs. 5, 6) show the association between rising food provisioning services, rising GDP and poverty alleviation. Figure 5 shows that rising agricultural production is coupled with poverty alleviation that is also evident in other countries (e.g. Niger, Afghanistan and Mexico) (WB 2013). But it is also possible to explore the links between rising GDP, a measure of economic growth, and environmental quality. Environmental Kuznets curves are simple bivariate plots showing the relationship between economic wealth and environmental quality through time (e.g. Beckerman 1992). A bivariate plot (Fig. 7) of relative

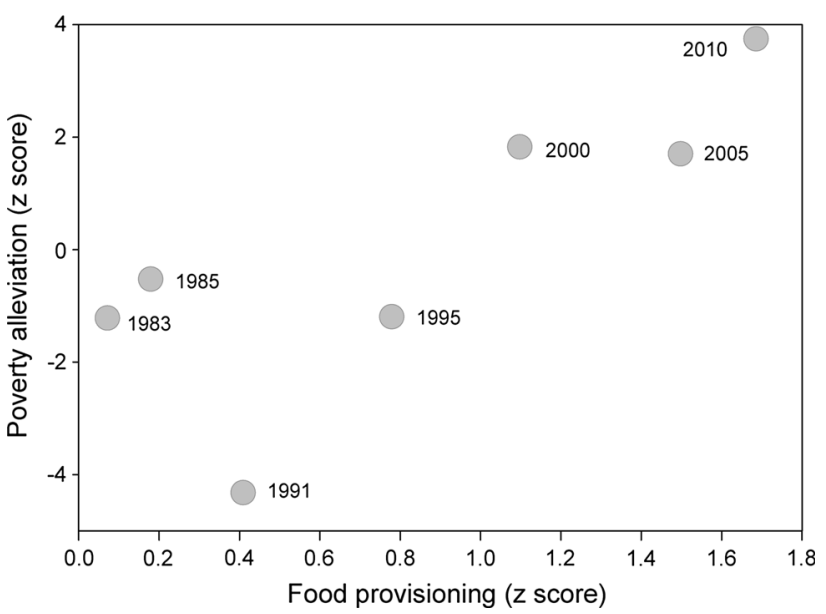

Fig. 5 Poverty alleviation versus food provisioning services (rice production), showing a strengthening relationship after 1991 


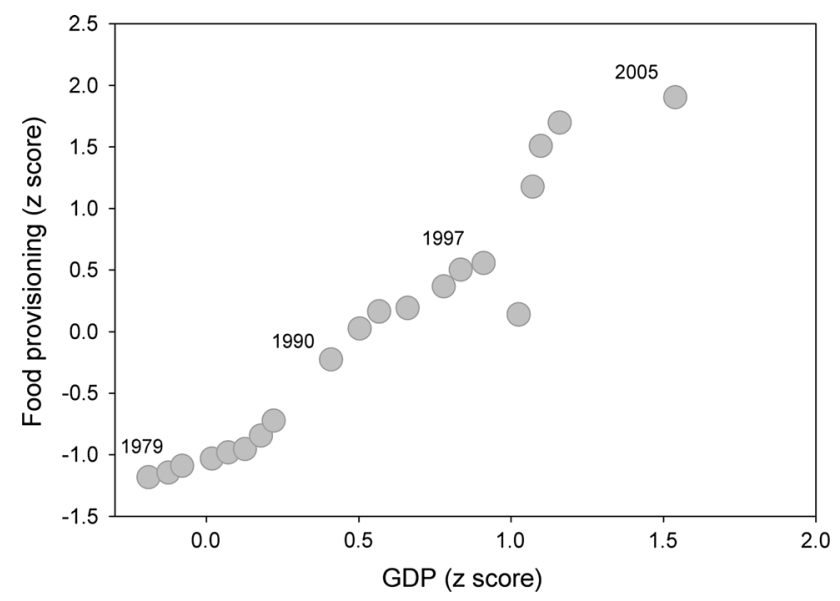

Fig. 6 Relative food provisioning services (rice production) versus GDP, showing overall a strong relationship

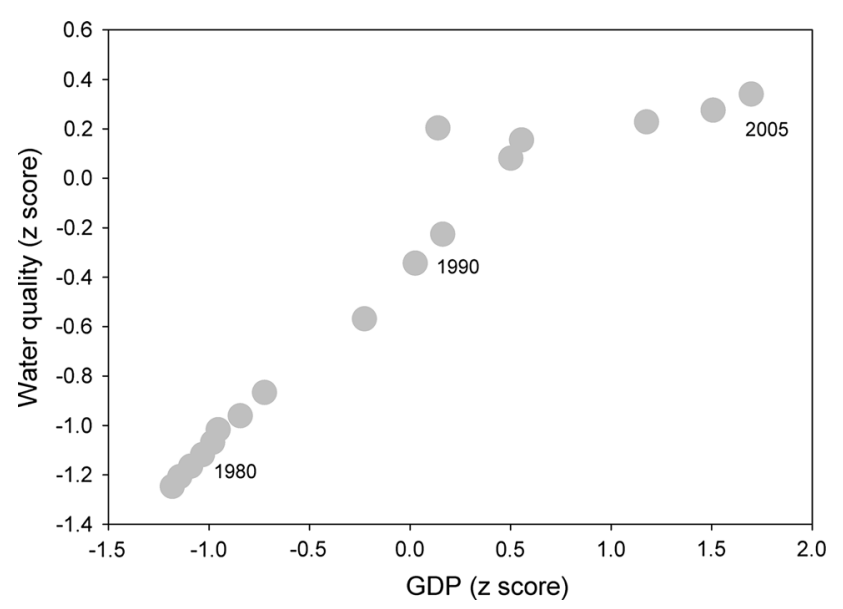

Fig. 7 Relative water quality (surface water salinity) versus GDP, where higher water quality $\mathrm{z}$ scores are interpreted as deteriorating water quality (similar to an Environmental Kuznets curve). The strong association since the 1970 s indicates that deteriorating water quality has been strongly coupled to economic growth, though the lower gradient after 2000 suggests a recent weakening

GDP against an index for water quality degradation (surface water salinity) in the $\mathrm{BCZ}$ shows that water resources have deteriorated as the Bangladesh economy has grown. In many middle- and high-income countries, the level of environmental degradation slows and reduces as GDP allows for investment in environmental remediation and protection measures. But in the $\mathrm{BCZ}$, there is no indication that this turning point has been reached.

But is a turning point possible? Direct actions to reduce degradation could include greater control on water quality through stronger regulation on the extent and practice of shrimp farming and on the exploitation of the mangroves. But external controls on river discharge and regional climate may mean that these can only be partially successful. Proactive adaptive strategies for managing agriculture, such as through the introduction of new crop hybrids, might also be introduced although the dependence of $\mathrm{T}$-Aman rice on irrigated water, obtained from declining resources, highlights the challenge of overcoming one problem without creating new ones or relying on environmental elements already stressed. The combined evidence from this study for declining resilience, possible tipping points and observable positive feedback mechanisms suggests growing unsustainability across the whole social-ecological system (cf. Zhang et al. 2015). Therefore, it is not unreasonable to suggest that a continuation of environmental degradation and losses of regulating services could eventually drive declines in rice, shrimp and fish production. This would impact first on rural poor farmers dependent on wage income or subsistence products, and gradually the larger landowners and associated processing industries. In time, a partial environmental improvement might occur as land became less intensively used. But in this scenario, it is unlikely that regional economic growth based on agriculture would continue. Rather than economic growth constraining environmental degradation, there would be a reversal or upturn of the Kuznets curve towards an earlier stage of development (cf. Liu 2012). Such a bleak prospect calls for the rapid involvement of scientists, stakeholders and politicians to negotiate a management plan for the BCZ.

\section{Conclusion}

Since the 1980s, increasing GDP and per capita income mirror rising levels of food and inland fish production. As a result, the size of population below the poverty line has reduced by $\sim 17 \%$ over the past 15 years. In contrast, nonfood ecosystem services such as water availability, water quality and land stability have deteriorated - at least by comparison with conditions in the 1960s. There is clear evidence for climate change from the early 1980s in terms of later monsoons and higher temperatures.

The extent to which the growing levels of food production and ecological deterioration are directly linked is difficult to judge, though conversion of rice fields to shrimp farms is almost certainly a factor in increasing soil and surface water salinity. An environmental Kuznets curve analysis suggests that the point at which growing wealth feeds back into effective environmental protection has not yet been reached for water resources.

The state of the Sundarbans mangrove forest is difficult to assess from the present data. The area of mangrove forest and production of timber forest products seem relatively stable, but declining tree density and volume suggest growing exploitation or fragmentation. 
There are multiple drivers of these changes in ecosystem services that range from global climate change and new agricultural methods to specific infrastructural developments (e.g. the Farakka barrage and polders), and localpolicy-driven actions (e.g. commercial shrimp farming). Most of the ecosystem services and well-being have experienced change points around 1980s, where water availability, shrimp farming and maintenance of biodiversity have passed tipping points.

Widespread trends in indicators of ecosystem services and human well-being point to non-stationary dynamics and slowly changing variables. As a result, theoretical arguments may be made for gradually declining resilience in agriculture and aquaculture with increased probability of positive feedbacks driving threshold changes/tipping points. There is evidence that high-magnitude events, such as large cyclones, that can potentially trigger threshold events are becoming more frequent. In the past, sequences of flooding and cyclones have reversed the long-term trend in poverty alleviation.

The historical database of ecosystem services and human well-being presented here is under construction and requires further data validation and analysis, but already provides a basis for hypothesis generation, model scenario development and model testing. This study serves as the basis for understanding the social-ecological complexities associated with regional scale sustainable development.

Acknowledgments The findings form part of the research undertaken within the project 'Assessing health, livelihoods, ecosystem services and poverty alleviation in populous deltas' (NE/J002755/1) funded by the Ecosystem Services for Poverty Alleviation Programme (ESPA). The UK ESPA programme is funded by the Department for International Development (DFID), the Economic and Social Research Council (ESRC) and the Natural Environment Research Council (NERC). We thank the Water Resources Planning Organization (WARPO) and Center for Environmental and Geographic Information (CEGIS) in Bangladesh for access to data. Md. Sarwar Hossain acknowledges financial support provided by a joint NERC/ ESRC interdisciplinary $\mathrm{PhD}$ studentship award and the University of Southampton. This is a Sustainability Science at Southampton publication.

Open Access This article is distributed under the terms of the Creative Commons Attribution License which permits any use, distribution, and reproduction in any medium, provided the original author(s) and the source are credited.

\section{References}

ADB (2005) Summery environmental impact assessment: south west area integrated water resources planning and management project in Bangladesh. Asian Development Bank (ADB)

Adel MM (2002) Man-made climate changes in the Ganges basin. Int J Climatol 22:993-1016. doi:10.1002/joc.732

Ahmed AU, Alam M, Rahman AA (1999) Adaptation to climate change in Bangladesh: future outlook. In: Huq S, Karim Z,
Asaduzzaman M, Mahtab F (eds) Vulnerability and adaptation to climate change for Bangladesh. Springer, Berlin, pp 125-143. doi:10.1007/978-94-015-9325-0_9

Ali A (1999) Climate change impacts and adaptation assessment in Bangladesh. Clim Res 12:109-116

Azad A, Jensen K, Lin C (2009) Coastal aquaculture development in Bangladesh: unsustainable and sustainable experiences. Environ Manag 44:800-809. doi:10.1007/s00267-009-9356-y

Bahar MM, Reza SM (2010) Hydrochemical characteristics and quality assessment of shallow groundwater in a coastal area of Southwest Bangladesh. Environ Earth Sci 61:1065-1073. doi:10. 1007/s12665-009-0427-4

BBS (2011) Bangladesh Bureau of Statistics (BBS). Peoples Republic of Bangladesh, Dhaka, Bangladesh. www.bbs.gov.bd/home.aspx

Beckerman W (1992) Economic growth and the environment. World Dev 20:481-496. doi:10.1016/0305-750X(92)90038-W

Beddoe R, Costanza R, Farley J, Garza E, Kent J, Kubiszewski I, Martinez L, McCowen T, Murphy K, Myers N, Ogden Z, Stapleton K, Woodward J (2009) Overcoming systemic roadblocks to sustainability: the evolutionary redesign of worldviews, institutions, and technologies. Proc Natl Acad Sci USA 106:2483-2489. doi:10.1073/pnas.0812570106

Biggs R, Schlüter M, Biggs D, Bohensky EL, BurnSilver S, Cundill G, Dakos V, Daw TM, Evans LS, Kotschy K, Leitch AM, Meek C, Quinlan A, Raudsepp-Hearne C, Robards MD, Schoon ML, Schultz L, Paul C, West PC (2012) Toward principles for enhancing the resilience of ecosystem services. Annu Rev Environ Resour 37:421-448. doi:10.1146/annurev-environ051211-123836

Binning C, Cork S, Parry R, Shelton D (2001) Natural assets: an inventory of ecosystem goods and services in the Goulburn Broken catchment. CSIRO Australia

Brazel A, Selover N, Vosel R, Heisler G (2000) The tale of two climates-Baltimore and Phoenix urban LTERsites. Clim Res 15:123-135. doi:10.3354/cr015123

Carpenter SR (2002) Ecological futures: building ecology of the long now. Ecology 83:2069-2083. doi:10.1007/s100210000043

Carpenter SR, Turner MG (2001) Hares and tortoises: interactions of fast and slow variables in ecosystems. Ecosystems 3:495-497

CBD (2010) Global biodiversity outlook 3. Convention on Biological Diversity (CBD), Montreal 94

CEGIS (2007) Effect of cyclone Sidr on the Sundarbans a preliminary assessment. Center For Environmental and Geographic Information Services CEGIS, Dhaka

Chaffey DR, Miller FR, Sandom, JH (1985) A Forest Inventory of the Sundarbans, Bangladesh. Project Report No. 140. Land Resources Development Center England

Chowdhury Q (2001) State of Sundarban. Forum of environmental journalist of Bangladesh, Ministry of Environment and Forest, Bangladesh (MoEF), United Nations Development Program (UNDP), Dhaka, Bangladesh

Costanza R, d'Arge R, de Groot R, Farber S, Grasso M, Hannon B, Limburg K, Naeem S, O’Neill RV, Paruelo J, Raskin RG, Sutton $\mathrm{P}$, van den Belt M (1997) The value of the world's ecosystem services and natural capital. Nature 387:253-259. doi:10.1038/ $387253 \mathrm{a} 0$

Danneberg J (2012) Changes in runoff time series in Thuringia, Germany-Mann-Kendall trend test and extreme value analysis. Adv Geosci 31:49-56. doi:10.5194/adgeo-31-49-2012

De Groot RS, Wilson MA, Boumans RMJ (2002) A typology for the classification, description and valuation of ecosystem functions, goods and services. Ecol Econ 41:393-408. doi:10.1016/S09218009(02)00089-7

De Groot RS, Stuip MAM, Finlayson CM, Davidson N (2006) Valuing wetlands: guidance for valuing the benefits derived from wetland ecosystem services. Ramsar Technical Report No. 
3/CBD Technical Series No. 27. Ramsar Convention Secretariat, Gland, Switzerland \& Secretariat of the Convention on Biological Diversity, Montreal, Canada

De Groot RS, Fisher B, Christie M, Aronson J, Braat L, HainesYoung R, Gowdy J, Maltby E, Neuville A, Polasky S, Portela R, Ring I (2010) Integrating the ecological and economic dimensions in biodiversity and ecosystem service valuation. In: Kumar $\mathrm{P}$ (ed) The economics of ecosystems and biodiversity (TEEB): ecological and economic foundations. Earthscan, London

Dearing JA, Bullock S, Costanza R, Dawson TP, Edwards ME, Poppy GM, Smith G (2012a) Navigating the perfect storm: research strategies for social-ecological systems in a rapidly evolving world. Environ Manag 49(4):767-775. doi:10.1007/s00267-0129833-6

Dearing JA, Yang X, Dong X, Zhang E, Chen X, Langdon PG, Zhang K, Zhang W, Dawson TP (2012b) Extending the timescale and range of ecosystem services through paleoenvironmental analyses, exemplified in the lower Yangtze basin. Proc Natl Acad Sci 109:1111-1120. doi:10.1073/pnas.1118263109

Dearing JA, Wang R, Zhang K, Dyke JG, Haberl H, Hossain MS, Langdon PG, Lenton TM, Raworth K, Brown S, Carstensen J, Cole MJ, Cornell SE, Dawson TP, Doncaster CP, Eigenbrod F, Flörken M, Jeffers E, Mackay AS, Nykvist B, Poppy GM (2014) Safe and just operating spaces for regional social-ecological system. Glob Environ Change 28:227-238. doi:10.1016/j. gloenvcha.2014.06.012

Deb U, Hoque Z, Khaled N, Bairagi SK (2008) Growth, income inequality and poverty trends in Bangladesh. Implications for Development Strategy, Centre for Policy Dialogue (CPD), Dhaka

Dey TK (2007) Deer population in the Bangladesh Sundarban. The Ad Communication, Chittagong

Ericksen NJ, Ahmad QK, Chowdhury AR (1997) Socio-economic implications of climate change for Bangladesh: briefing document no. 4. Bangladesh Unnayan Parishad (BUP), Dhaka, Bangladesh

FAO (1999) Forest resources of Bangladesh. Country report, working paper no. 15, Rome, Italy

FAO (2007) Mangroves of Asia 1980-2005. Country reports, forest resources assessment programme,working paper 137, food and agriculture organization of the United Nations. ftp.fao.org/ docrep/fao/010/ai444e/ai444e00.pdf. Accessed 3 Jan 2013

Fisher B, Turner RK (2008) Ecosystem services: classification for valuation. Biol Conserv 141(5):116-1167. doi:10.1016/j.biocon. 2008.02.019

Folke C, Hahn T, Olsson P, Norberg J (2005) Adaptive governance of social-ecological systems. Annu Rev Environ Resour 30:441-473. doi:10.1146/annurev.energy.30.050504.144511

Gittings SP (1980) A survey of the primates of Bangladesh. Flora and fauna preservation. London and Cond Conserv Tr UK

Grossman GM, Krueger AB (1995) Economic growth and the environment. Q J Econ 110:353-377. doi:10.3386/w4634

Helalsiddiqui ASM (1998) Sundarban at a glance. Mangrove Siviculture Research Division of Bangladesh Forest Research Institute, Khulna 63

Hendrick HH (1975) The Status of the tiger (panthera tigris, linne 1758). Saugetiere Mitt 23(3):161-199

Hirsch RM, Alexander RB, Smith RA (1991) Selection of methods for the detection and estimation of trends in water quality. Water Resour Res 27(5):803-813. doi:10.1029/91WR00259

Hossain MS, Hein L, Rip F, Dearing J (2013) Integrating ecosystem services and climate change responses in coastal wetlands developments plans for Bangladesh. Mitig Adapt Strat Glob Change. doi:10.1007/s11027-013-9489-4

Hossain MS, Roy K, Datta D (2014) Spatial and temporal rainfall variability of rainfall over the south west coast of Bangladesh. Climate 2(2):28-46. doi:10.3390/cli2020028
Husain AMM, Hossain M, Janaiah A (2001) Hybrid rice adoption in Bangladesh: a socioeconomic assessment of farmers' experiences. Research monograph series no. 18, BRAC and international rice research institute, Dhaka, Bangladesh

Iftekhar MS, Islam MR (2004) Degeneration of Bangladesh's Sundarbans mangroves: a management issue. Int For Rev 6(2):123-135. doi:10.1505/ifor.6.2.123.38390

Iftekhar MS, Saenger P (2008) Vegetation dynamics in the Bangladesh Sundarbans mangroves: a review of forest inventories. Wetl Ecol Manag 16:291-312. doi:10.1007/s11273-007-9063-5

Inoue T, Matsumoto J (2007) Abrupt climate changes observed in late August over central Japan between 1983 and 1984. J Clim 20:4957-4967. doi:10.1175/JCLI4217.1

Islam MR (2006) Managing diverse land uses in Coastal Bangladesh: institutional approaches. In: Hoanh CT, Tuong TP, Gowing JW, Hardy B (eds) Environment and livelihoods in Tropical Coastal Zones. $\mathrm{CAB}$ International and International Rice Research Institute (IRRI), Manila. doi:10.1079/9781845931070.0237

Islam MSN (2008) Cultural landscape changing due to anthropogenic influences on surface water and threats to mangrove wetland ecosystems: a case study on the Sundarbans, Bangladesh. $\mathrm{PhD}$ Dissertation, Brandenburg University of Technology at Cottbus Germany

Islam MB, Ali MY, Amin M, Zamon SM (2011) climatic variations: farming systems and livelihoods in the high barind tract and coastal areas of Bangladesh. In: Lal R, Sivakumar MVK, Faiz SMA, Rahman AHMM, Islam KR (eds) Climate change and food security in South Asia. Springer, Berlin, pp 477-488. doi:10.1007/978-90-481-9516-9_29

IUCN (1997) Sundarban Wildlife Sanctuaries Bangladesh. International Union for Conservation of Nature (IUCN). http://whc. unesco.org/archive/advisory_body_evaluation/798.pdf. Accessed 20 Jan 2013

Kallis G, Norgaard RB (2010) Coevolutionary ecological economics. Ecol Econ 69:690-699. doi:10.1016/j.ecolecon.2009.09.017

Khan MMH (2005) Project Sundarban tiger: tiger density and tigerhuman conflict. Financial Technical Report. save the tiger fund of the national fish and wildlife foundation, USA. http://www. panthera.org/sites/default/files/STF/2005-0013-004.pdf. Accessed 2 Apr 2013

Khan TMA, Sing OP, Rahman S (2000) Recent sea level and sea surface temperature trends along the Bangladesh coast in relation to the frequency of intense cyclones. Mar Geod 23:103-116. doi:10.1080/01490410050030670

Liu L (2012) Environmental poverty, a decomposed environmental Kuznets curve, and alternatives: sustainability lessons from China. Ecol Econ 73:86-92. doi:10.1016/j.ecolecon.2011.10.025

Liu J, Dietz T, Carpenter SR, Alberti M, Folke C, Moran E, Pell AN, Deadman P, Ostrom E, Ouyang Z, Provencher W, Redman CL, Schneider SH, Taylor WW (2007) Complexity of coupled human and natural systems. Science 317:1513-1516. doi:10.1126/science. 1144004

MA (2005) Ecosystems and human well-being: a framework for assessment. Millennium ecosystem assessment. Island Press, Washington

Maplecroft (2010) Big economies of the future - Bangladesh, India, Philippines, Vietnam and Pakistan - most at risk from climate change 21st Oct 2010. http://maplecroft.com/about/news/ccvi. html. Accessed 20 Mar 2013

Mirza MQ (1997) Hydrological changes in the Ganges system in Bangladesh in the post-Farakka period. Hydrol Sci J Sci Hydrol 42(5):613-631. doi:10.1080/02626669709492062

Mirza MQ (1998) Diversion of the Ganges water at Farakka and its effects on salinity in Bangladesh. Environ Manag 22(5):711-722. doi: $10.1007 / \mathrm{s} 002679900141$ 
Mirza MM, Ericksen NJ (1996) Impact of water control projects resources in Bangladesh on fisheries. Environ Manag 20(4):523-539. doi:10.1007/BF01474653

MoEF (2002) Survey to determine the relative abundance of tiger wild boar and spotted deer in the Bangladesh Sundarban forest during December.2001 to March 2002. Technical reports-TR No.17, Ministry of environment and forest (MoEF), Dhaka, Bangladesh

MoEF (2005) National adaptation programme of action (NAPA). Ministry of environment and forest (MoEF) Dhaka, Bangladesh. http://unfccc.int/resource/docs/napa/ban01.pdf. Accessed 10 Jan 2013

MoEF (2010) Fourth National report to the convention on biological diversity: biodiversity national assessment and programme of action 2020. Ministry of Environment and Forests (MoEF), Dhaka

Norgaard RB (2010) Ecosystem services: from eye-opening metaphor to complexity blinder. Ecol Econ 69:1219-1227. doi:10.1016/j. ecolecon.2009.11.009

OECD (2001) The well-being of nations: the role of human and social capital. Organization for Economic Co-operation and Development (OECD), Paris

Ostrom E (2007) A diagnostic approach for going beyond panaceas. Proc Natl Acad Sci USA 104:15181-15187. doi:10.1073/pnas. 0702288104

Petz K, Minca EL, Werners SE, Leemans R (2012) Managing the current and future supply of ecosystem services in the Hungarian and Romanian tisza river basin. Reg Environ Change 12:689-700. doi:10.1007/s10113-012-0284-7

Rahman A, Rabbani G, Muzammil M, Alam M, Thapa S, Rakshit R, Inagaki $H$ (2010) Scoping assessment on climate change adaptation in Bangladesh. AIT-UNEP PRC, AP, Thailand

Rahman MH, Lund T, Bryceson I (2011) Salinity impacts on agrobiodiversity in three coastal, rural villages of Bangladesh. Ocean Coast Manag 54:455-468. doi:10.1016/j.ocecoaman.2011.03. 003

Salim M, Maruf BU, Sumsuddoha M, Chowdhury AI, Babul AR (2007) Climate change would intensify river erosion in Bangladesh: climate change impact in Bangladesh. campaign brief 6 , equity and justice working group-EJWG, COAST trust, Dhaka, Bangladesh

Sarwar MGM (2005) Impacts of sea level rise on the coastal zone of Bangladesh. MSc Dissertation. Programme in environmental science, Lund University, Sweden

Serrano A, Mateos VL, Garcia JA (1999) Trend analysis of monthly precipitation over the Iberian Peninsula for the Period
1921-1995. Phys Chem Earth 24(1-2):85-90. doi:10.1016/ S1464-1909(98)00016-1

Swapan MSH, Gavin M (2011) A desert in the delta: participatory assessment of changing livelihoods induced by commercial shrimp farming in Southwest Bangladesh. Ocean Coast Manag 54:45-54. doi:10.1016/j.ocecoaman.2010.10.011

Uddin MN, Haque A (2010) Salinity response in southwest coastal region of Bangladesh due to hydraulic and hydrological parameters. Int J Sustain Agric Technol 6(3):01-07

Vitale D, Rana G, Soldo P (2010) Trends and extremes analysis of daily weather data from a site in the capitanata plain (Southern Italy). Italy J Agron 5:133-143. doi:10.4081/ija.2010.133

Walker BH, Carpenter SR, Rockstrom J, Crépin AS, Peterson GD (2012) Drivers, "slow" variables, "fast" variables, shocks, and resilience. Ecol Soc 17(3):30. doi:10.5751/ES-05063-170330

Wang R, Dearing JA, Langdon PG, Zhang E, Yang X, Dakos V, Scheffer M (2012) Flickering gives early warning signals of a critical transition to a eutrophic lake state. Nature 492:419-422. doi:10.1038/nature11655

WB (2000) Bangladesh: climate change and sustainable development report no. 21104, rural development unit. South Asia region, World Bank (WB)

WB (2013) Agriculture: sectors results profile. An engine for sustainable growth and poverty reduction. World Bank (WB). www.worldbank.org/en/results/2013/04/15/agriculture-resultsprofile. Accessed 23 Aug 2014

Wilkinson L (1997) SYSTAT 7.0 Statistics. SPSS Inc, Chicago

WRI (2013) Ecosystem service indicators database. Word Resource Institute, Washington, USA. http://www.esindicators.org/indica tor_details/1132. Accessed 20 Mar 2013

Wünscher T, Engel S, Wunder S (2008) Spatial targeting of payments for environmental services: a tool for boosting conservation benefits. Ecol Econ 65(4):822-833. doi:10.1016/j.ecolecon.2007. 11.014

Zhang Q, Xu YC, Yang T (2009) Variability of water resource in the yellow river basin of past 50 years, china. Water Resour Manag 23:1157-1170. doi:10.1007/s11269-008-9320-2

Zhang K, Dearing JA, Dawson TP, Dong X, Yang X, Zhang W (2015) Poverty alleviation strategies in eastern China lead to critical ecological dynamics. Sci Total Environ 506-507:164-181. doi:10.1016/j.scitotenv.2014.10.096

Zmarlicki CB (1994) Integrated Resources Development of The Sundarbans Reserved Forest, Bangladesh. United Nations Development Organization and Food and Agriculture Organization of the United Nations. Rome, Italy 